\title{
Are healthcare professionals working in Australia's immigration detention centres condoning torture?
}

\author{
David Isaacs ${ }^{1,2}$
}

${ }^{1}$ Department of Infectious Diseases \& Microbiology, Children's Hospital at Westmead, Sydney, New South Wales, Australia

${ }^{2}$ Discipline of Child Health, University of Sydney, Sydney, New South Wales, Australia

\section{Correspondence to} Professor David Isaacs, Children's Hospital at Westmead, Sydney, Locked Bag 4001, Sydney, NSW 2145, Australia; david.isaacs@health. nsw.gov.au

Received 13 August 2015 Revised 22 October 2015 Accepted 28 October 2015 Published Online First 23 December 2015

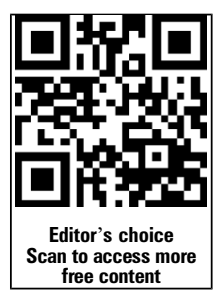

\section{SLinked}

- http://dx.doi.org/10.1136/ medethics-2015-103326

- http://dx.doi.org/10.1136/ medethics-2016-103371

- http://dx.doi.org/10.1136/ medethics-2016-103387

\section{CrossMark}

To cite: Isaacs D. J Med Ethics 2016:42:413-415.

\section{ABSTRACT}

Australian immigration detention centres are in secluded locations, some on offshore islands, and are subject to extreme secrecy, comparable with 'black sites' elsewhere. There are parallels between healthcare professionals working in immigration detention centres and healthcare professionals involved with or complicit in torture. In both cases, healthcare professionals are conflicted between a duty of care to improve the health of patients and the interests of the government. While this duality of interests has been recognised previously, the full implications for healthcare professionals working in immigration detention have not been addressed. The Australian Government maintains that immigration detention is needed for security checks, but the average duration of immigration detention has increased from 10 weeks to 14 months, and detainees are not informed of the progress of their application for refugee status. Long-term immigration detention causes major mental health problems, is illegal in international law and arguably fulfils the recognised definition of torture. It is generally accepted that healthcare professionals should not participate in or condone torture. Australian healthcare professionals thus face a major ethical dilemma: patients in immigration detention have pressing mental and physical health needs, but providing healthcare might support or represent complicity in a practice that is unethical. Individual healthcare professionals need to decide whether or not to work in immigration detention centres. If they do so, they need to decide for how long and to what extent restrictive contracts and gagging laws will constrain them from advocating for closing detention centres.

Australia has had a legislated policy of mandatory detention of people who arrive without a visa since 1992, supported by both major political parties. ${ }^{1}$ Increasingly, draconian legislation has been aimed at people seeking asylum, particularly those arriving by boat. ${ }^{2}$

Ethical concerns for Australian healthcare professionals working in immigration detention have been discussed previously. ${ }^{3-6}$ The major conflict of interest is dual loyalty to patients and to the government or to the private healthcare organisation contracted by the government to provide healthcare, International Health and Medical Services (IHMS). All healthcare professionals who work for IHMS sign restrictive contracts forbidding criticism of the care provided by IHMS or the government in either social or mainstream media. Secrecy, which characterises recent Australian Government policy on people seeking asylum, itself creates ethical issues for healthcare professionals. If they speak up to expose harms to health caused by immigration detention, they will no longer be employed and thus unable to directly improve patient health. They may even face imprisonment: the Australian Border Force Act 2015 threatens Government-contracted workers, including doctors, nurses and teachers, with up to 2 years in prison if they reveal the truth about circumstances in immigration detention centres. ${ }^{7}$

Boats of people seeking asylum coming from Indonesia arrive at Christmas Island, a tiny Australian territory in the Indian Ocean with a population of 2000, named for its discovery on Christmas Day 1643. To avoid its international responsibility to people seeking asylum and arriving by boat, reminiscent of Guantanamo Bay, Australia 'excised' Christmas Island from the mainland. Later, with extraordinary sleight of hand and in contravention to international law, Australia excised the mainland from the migration zone. ${ }^{2}$ Some people who reach Christmas Island by boat from Indonesia are flown to remote offshore detention centres on Nauru and Manus Island. The living conditions for asylum seekers in Nauru, the smallest state in the South Pacific (population $<10000$ ), and Manus Island in northern Papua New Guinea, are extraordinarily harsh (box 1). ${ }^{7-10}$

A report by the United Nations' special rapporteur on torture, Juan Mendez, found Australia guilty of violating the human rights of asylum seekers on multiple fronts under the Convention Against Torture and Other Cruel, Inhuman or Degrading Treatment or Punishment, although he was not explicit in which way. ${ }^{12}$ Ex-Prime Minister Tony Abbott's response was "Australians are sick of being lectured to by the United Nations." The United Nations defines torture as

\footnotetext{
'... any act by which severe pain or suffering, whether physical or mental, is intentionally inflicted on a person for such purposes as obtaining from him or a third person information or a confession, punishing him for an act he or a third person has committed or is suspected of having committed, or intimidating or coercing him or a third person, or for any reason based on discrimination of any kind, when such pain or suffering is inflicted by or at the instigation of or with the consent or acquiescence of a public official or other person acting in an official capacity. It does not include pain or suffering arising only from, inherent in or incidental to lawful sanctions'. ${ }^{13}$
}

In the past, some Australian healthcare professionals have helped force-feed detainees who go on hunger strike and helped chemically restrain people for deportation, ${ }^{3}$ acts that collude with significant infringements of autonomy and human rights. There is a case that prolonged immigration 
Box 1 Personal experience of Australian immigration detention

In December 2014, a paediatric nurse and I travelled to Nauru to consult on children in detention. ${ }^{8}$ The conditions we witnessed typified those described by Goffman as occurring in institutions such as asylums, prisons and concentration camps, which he characterises as causing 'mortification of the self'. ${ }^{11}$ Detainees lacked privacy. Families were housed in adjoining tents, and guards walk in without warning. Showers and toilets were up to $120 \mathrm{~m}$ away. At night, the long dark walk under the eyes of guards was enough to deter many women and children, who wet the bed, then put the mattress out to dry in the sun. Shower time was limited; guards would offer longer if women exposed themselves. There was constant bullying and humiliation. We also observed dehumanisation and denial of personhood: children and adults coming to the medical centre are referred to by their boat numbers. When we asked why, we were told 'there are too many Mohammads'. Such acceptance of the normalisation of dehumanisation by healthcare professionals has been described previously. ${ }^{4}$ One woman confided she had been raped at night by a cleaner, but did not want her husband to know. We organised for a female psychologist to see her. Next day, the psychologist described how the woman dressed provocatively and described asking her why she had not cried out when being raped. This victim-blaming approach typified how many International Health and Medical Services (IHMS) staff had come to see people seeking asylum as guilty and unworthy of normal human consideration. The average length of detention of the children and families was 14 months, and they were still not told when their applications for asylum would be processed.

detention itself constitutes torture. The government argues that short-term immigration detention is needed for security checks, but the average length of detention for those in immigration detention has risen from 10 weeks to 14 months without any explanation of the reason. ${ }^{14}$ Furthermore, detainees are not informed of when if ever their detention will end, which renders them powerless and increases stress. Convicted criminals in prison at least know their release date; in contrast, asylum seekers, who have committed no criminal offence, are not kept informed of their fate. There is strong evidence that prolonged immigration detention results in severe mental health problems including anxiety, depression, post-traumatic stress disorder, self-harm and suicidality. ${ }^{15-19}$ Time in detention correlates with severity of mental health problems and, despite an initial improvement after release, the negative mental health impact of detention persists. ${ }^{18}$ It could be argued that prolonged detention of someone convicted of a serious crime could constitute torture under this argument. However, because asylum seekers have committed no crime, their imprisonment is unjust, and their sense of grievance at injustice will likely increase the harm. In addition, the uncertainty of their future and loss of control compound the suffering. While the Australian Government does not specify the intention of prolonged immigration detention, it is arguably to coerce asylum seekers into voluntarily returning to their own or another country and to deter others from seeking asylum. Prolonged detention without trial is illegal in Australia, as in most other democratic countries, and can be challenged in law with a writ of habeas corpus..$^{20}$ Severe harms that befall asylum seekers as a result of prolonged immigration detention arguably fulfil the definition of torture in being suffering that is intentionally and unlawfully inflicted through agencies influenced by the Australian Government with the intention of coercion and deterrence.

Healthcare professionals have a clear responsibility not to participate in or condone torture. ${ }^{21} 22$ The US Central Intelligence Agency still maintains that atrocities perpetrated post-9/11 were not torture because techniques such as waterboarding were developed by psychologists and overseen by doctors. ${ }^{23}$ The Hippocratic Oath declares, 'I will use treatment to help the sick according to my ability and judgment, but never with a view to injury and wrongdoing'. How do doctors ever become complicit in torture? First, authorities tell doctors that they are immune from prosecution and are fulfilling a vital role protecting their country against terrorism. ${ }^{21}$ Institutions are often offshore, out of sight and mind, so-called 'black sites'. ${ }^{21}$ It is chilling that the majority of Nazi concentration camps were outside Germany. The offshore detention centres used by Australia are clearly 'black sites'.

Incidentally, doctors working in institutions practising torture have another conflict of interest: they usually receive significant financial and career incentives. ${ }^{19}{ }^{21}$ Financial conflict of interest is relevant to IHMS that remunerate staff well.

Many Australians argue that what happens to people seeking asylum who are placed in detention cannot be compared with the waterboarding and other atrocities perpetrated in $\mathrm{Abu}$ Ghraib. ${ }^{24}$ It might be argued that there are degrees of torture, and what happens to people in immigration detention is less morally reprehensible than what happens to other innocent persons in prisons throughout the world, such as political prisoners. Short-term detention does not fulfil the United Nations' definition of torture, whereas long-term detention does. However, grading severity of torture is potentially hazardous: are we to wait until people have been in immigration detention long enough to constitute torture? Involvement of healthcare professionals in prolonged immigration detention is at least analogous to healthcare professional involvement in torture. If prolonged immigration detention does constitute torture, then are healthcare professionals morally justified in working in such a system at all? The major moral argument in favour of working with people in immigration detention is to provide best possible healthcare and that not to do so would involve a dereliction of a healthcare professional's duty of care. This is a strong argument. Healthcare professionals have contemplated boycotting working in immigration detention centres, that is, instituting a call for healthcare professionals to refuse to work in immigration detention. ${ }^{7}$ The ethical issues have been discussed previously. ${ }^{5}$ A boycott would almost certainly not be successful in improving the health of detainees in the short- or long term, which does not necessarily alter its moral weight. The tension between care and collusion has been discussed previously. ${ }^{3-6}$ Healthcare professionals looking after detainees face a moral conflict between their primary obligation to the patient and their obligations to institutions and employers. ${ }^{25}$ It could be argued that healthcare professionals in immigration detention centres are ideally placed to work towards better conditions for detainees. IHMS use this justification for working with the Australian Government. ${ }^{26}$ The Red Cross uses a similar argument and never addresses politics, although it does not have a comparable financial conflict with IHMS. In contrast, Médecins Sans Frontières argue that they will not provide healthcare to a country unless they are free to comment on political factors affecting health. It could be argued that doctors and nurses have 
a moral duty both to serve and to speak out. The testimony of those who have witnessed what happens in detention centres is sought by mainstream media and apparently carries more weight with the public. However, the restrictive contracts and legislation in Australia mean that those who do speak out will not be re-employed in detention centres and face possible retribution. ${ }^{27}$

Australian healthcare professionals can and do currently advocate for the closure of or release of children from immigration detention centres on healthcare grounds. Each individual practitioner faces the moral dilemma of whether to work in immigration detention at all and effectively condone what amounts to torture, and if they do work there, they must decide for how long and to what extent they report on harms.

Acknowledgements The author thanks Alanna Maycock who stood up to bullying guards on Nauru and taught me about courage and recognising and confronting injustice. I thank Vicki Xafis for helpful comments.

Competing interests DI was paid for providing specialist paediatric services in Nauru, and donated all proceeds to the Children's Hospital at Westmead Refugee Clinic.

Provenance and peer review Not commissioned; externally peer reviewed.

\section{REFERENCES}

1 Refugee Council of Australia. Mandatory detention. 2014. http://www. refugeecouncil.org.au/fact-sheets/asylum-seeker-issues/mandatory-detention/ (accessed 18 Sept 2015).

2 Barlow K. Parliament excises mainland from migration zone. ABC News, 2013. http://www.abc.net.au/news/2013-05-16/parliament-excises-mainland-frommigration-zone/4693940 (accessed 18 Sept 2015).

3 Briskman L, Zion D, Loff B. Challenge and collusion: Health professionals and immigration detention in Australia. Int J Human Rights 2010;14:1092-106.

4 Briskman L, Zion D, Loff B. Care or collusion in asylum seeker detention. Ethics Soc Welfare 2012;6:37-55.

5 Sanggaran J-P, Ferguson GM, Haire BG. Ethical challenges for doctors working in immigration detention. Med J Aust 2014;201:377-8.

6 Essex R. Human rights, dual loyalties, and clinical independence. J Bioeth Enq 2014;11:75-83.

7 Isaacs D. Doctors should boycott working in Australia's immigration centres and must continue to speak out on mistreatment of detainees - despite the law. BMJ 2015;350:h3269.

8 Isaacs D. Nauru and detention of children. J Paediatr Child Health 2015;51:353-4
9 Paxton G, Tosif S, Graham H, et al. Perspective: 'The forgotten children: national inquiry into children in immigration detention (2014)'. J Paediatr Child Health 2015;51:365-8.

10 The Forgotten Children: National Inquiry into Children in Immigration Detention (2014). Sydney: Australian Human Rights Commission, 2014. http://www. humanrights.gov.au/publications/forgotten-children-national-inquiry-childrenimmigration-detention-2014 (accessed 18 Sept 2015).

11 Goffman E. Asylums. New York: Anchor Books, 1961.

12 Office of the High Commissioner for Human RightsMendez JE. Report of the Special Rapporteur on torture and other cruel, inhuman or degrading treatment or punishment. A/HRC/28/68, 2015. http://www.ohchr.org/EN/Issues/Torture/SRTorture/ Pages/SRTorturelndex.aspx (accessed 18 Sep 2015).

13 United Nations General Assembly. Convention against Torture and Other Cruel, Inhuman or Degrading Treatment or Punishment. Geneva: UN. A/RES/39/46, 1984. http://www.un.org/documents/ga/res/39/a39r046.htm (accessed 18 Sep 2015).

$14 A B C$ News. Fact check: Triggs correct on the length of time children spent in detention. ABC, 2015. http://www.abc.net.au/news/2015-02-23/triggs-detention/ 6083476 (accessed 18 Sep 2015).

15 Sultan A, O'Sullivan K. Psychological disturbances in asylum seekers held in long term detention: a participant-observer account. Med J Aust 2001;175:593-6.

16 Steel Z, Momartin S, Bateman C, et al. Psychiatric status of asylum seeker families held for a protracted period in a remote detention centre in Australia. Aust NZ Public Health 2004;28:527-36.

17 Mares $S$, Jureidini J. Psychiatric assessment of children and families in immigration detention--clinical, administrative and ethical issues. Aust NZ J Public Health 2004;28:520-6.

18 Robjant K, Hassan R, Katona C. Mental health implications of detaining asylum seekers: systematic review. Br J Psychiatry 2009;194:306-12.

19 Dudley M, Steel Z, Mares S, et al. Children and young people in immigration detention. Curr Opin Psychiatry 2012;25:285-92.

20 Clark D, McCoy G. Habeas corpus. Sydney, Australia: Federation Press, 1998.

21 Annas GJ. Military medical ethics - Physician first, first, last and always. N Engl J Med 2008;359:1087-90.

22 Annas GJ, Crosby SS. Post-9/11 torture at CIA "black sites" - physicians and lawyers working together. N Engl J Med 2015;372:2279-80.

23 United States Senate Select Committee on Intelligence. Committee Study of the Central Intelligence Agency's Detention and Interrogation Program together with Foreword by Chairman Feinstein and Additional and Minority Views (December 9, 2014). http://www.intelligence.senate.gov/publications/committee-study-centralintelligence-agencys-detention-and-interrogation-program (accessed 12 August 2015).

24 Miles SH. Abu Ghraib: its legacy for military medicine. Lancet 2004;364:725-9.

25 Sheather J, Benyon R, Davies T, et al. Torture and doctors' dual obligation. BMJ 2015; 350:h589.

26 Parrish M, Renshaw A, Duncombe GJ, et al. Antenatal care for asylum seekers. Med J Aust 2015;202:12-13.

27 Gunasekera H, Isaacs D. Antenatal care for asylum seekers. Med J Aust 2015;202:572. 